\title{
LIQUID NITROGEN SUBCOOLER PRESSURE VESSEL ENGINEERING NOTE
}

Author: Russ Rucinski, PPD/ETT/D $\varnothing$

April 24, 1997

Approved:

PPD/ETT/D-Zero Meqhanicalforoup leader 


\section{PER CHAPTER 5031}

Prepared by: ANDREW KUWAZAKJ

Preparation date: $1 / 31 / 47$

1. Description and Identification

Fill in the ladel information below:

This vessel conforms to Fermilab ES\&B Manual Chapter 5031

vessel TItIe LIQUID NITROGEN SUBCOOLER

Vessel Number

$P P D-10050$

Obtain from Safety officer

Division/Section

Vessel Drawing Number 3823.115-ME - 317304

Maximum Allowable

Working Pressure

(MAWP) $\quad: 50$

PSIG

Working Temperature Range -320 OF $100 \quad{ }_{F}$

Contents LLQUID NITREGEN

Designer/Manufacturer MINNESOTA YALCY

ENGINEERING

Test pressure (if tested at Fermi) Acceptance

Date:

Document per Chapter

5034 of the Fermilab

ES\&B Manual

PSI, Bydraulic

Pneumatic

Accepted 25 gonforming to standard by

Accepted

of

Partide Preysionate: $4(2 z / 9)$

Actual signature required

NOTE: AnY subsequent changes in contents, pressures, temperatures, valving, etc., which affect the safety of this vessel shall require another revifw.

Reviewed by<smiles>[Te]C1CCCCC1</smiles>

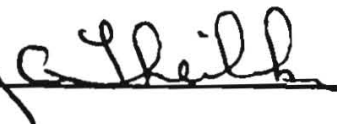
Date: $4 / 2 / 97$

Director's slgnature (or designee) if the vessel is for manned areas but doesn't conform to the requirements of the chapter.

Date:

Arsanoment No. :

Fermilab ES\&H Manual
Rev1ewed by:

Date : 
Lab Property Number(s):

N/A

Lab Location Code: 325 (obtain from safety officer)

Purpose of vessel(s): LIQUID NITROGEN CONTAINER FOR UPGRADE

Vessel Capacity/size: $1.3 \mathrm{ft}$. Dsameter: $\frac{13}{\text { PSIG }}$

Normal Operating Pressure (OP) 1,5 Length: $16^{\circ}$

MAWP-OP = 48.5 PSIG

* the normal operating pressure of this dewar is EXPECTED TO BE LESS THAN 1.5 PSIG. THIS VESSEL IS OPEN TO ATMOSPHERIC PRESSURE THRU A NON- ISOLATABLE VENT LINE. THE backPressure in the vent line was callculated TO bE LESS THAN 1.5 PSIG at MAXIMUM anticipated flow RATES. 
List the numbers of all pertinent drawings and the location of the originals.

Drawling

Location of Original

$3823.115-M E-317304$

DQ MAIN BUILDING - HIGH BAY

2. Design Verificat10n

BOTTOM TOP

Does the vessel(s) have a U stamp? Yes $X$ No $X$. If "Yes", f111 out data below and skip page 3; if "No", fill out page 3 and skip this page.

Staple photo of U stamp plate below.

Copy "Un" label detalls to the side

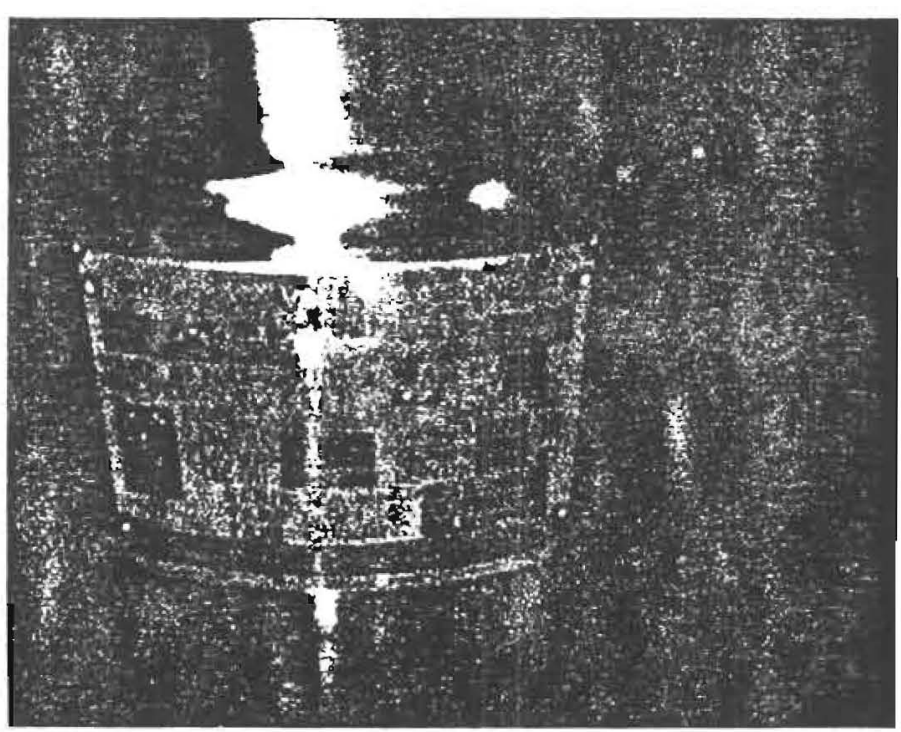

Copy data here:

Minnesota Valley Engineering

$I-1$ Dewar $W / B$ Flange MAWP at Full Vacuum 65 psi

at $100^{\circ} \mathrm{F}$

Min. Design Metal Temp.: $-320^{\circ} \mathrm{F}$ at 65 psi

Serial No. 496

Year Built: 1995

Tare Weight: 74 los. 
Provide ASME design calculations in an appendix. On the sketch below, circle all applicable sections of the ASME code per section VIII, Division I. (only for non-coded vessels)

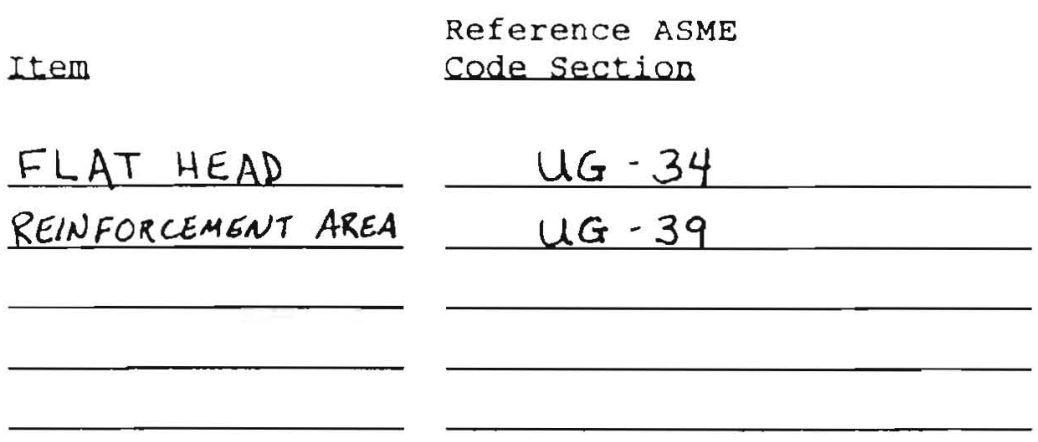

\section{CALCULATION RESULT}

(Required thickness or stress level vs. actual thickness calculated stress leveil)

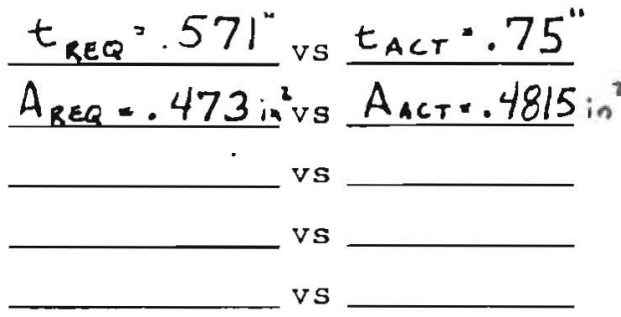


3. System Venting Veriflcation Provide the system schematic in the Appendix.

Is it possible to isolate the relief valves by a valve from the vessel? Yes__ No X

If "Yes", the system must conform to code rules. Provide an explanation on the appended schematic. (An isolatable ressel, not conforming to code rule is non-compliant under this chapter.)

Is the relief cracking pressure set at or below the M.A.W.P.? Yes $X$ No_ Actual setting 50 PSI

(A "No" response violates this chapter.)

Is the pressure drop of the relief system at maximum anticipated flow such that vessel pressure never rises above the following? (UG 125)
Yes $X$ No
1108 of MAWP (one relief)
1168 of MAWP (multiple reliefs)
1218 of MAWP (unexpected heat source)

Provide test or calculational proof in the Appendix.

(Non-conforming pressure rises is non-compliant under this chapter.)

List of reliefs and settings:

Manufacturer

Model \# Set pressure Elow Rate

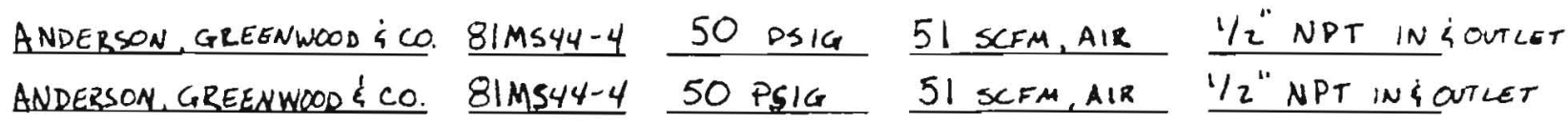

Does the primary relief device follow UG-129? Yes $X$ No

(A "No" response is non-compliant under this chapter)

4. Operating Procedure

Is an operating procedure necessary for the safe operation of this vessel?

Yes_ No_ $X$ (If "Yes", it must be appended)

5. Welding Information

TOP (FERM I) BOTTOM

Has the vessel been fabricated in a non-code shop? Yes $X$ No $X$ If "Yes", append a copy of the welding shop statement of welder qualification (Procedure Qualification Record, PQR) which references the Welding procedure Specification (WPS) used to weld this vessel. 
6. Except1onal, Existing, Used and Inmanned Area Vessels

Is this vessel or any part thereof in the above categories?

Yes No

If "Yes", follow the Engineering Note requirements for documentation and append to Note. 


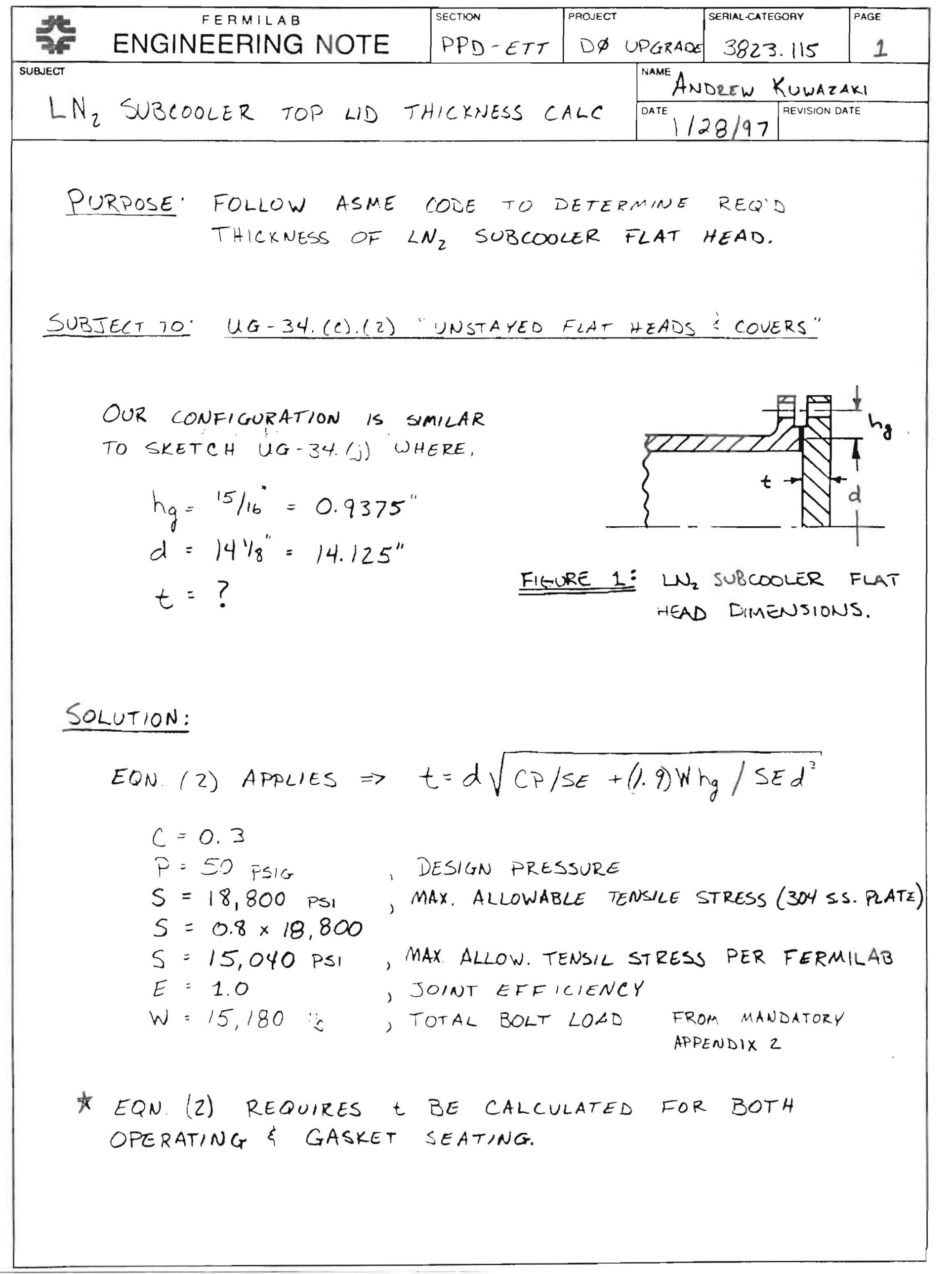




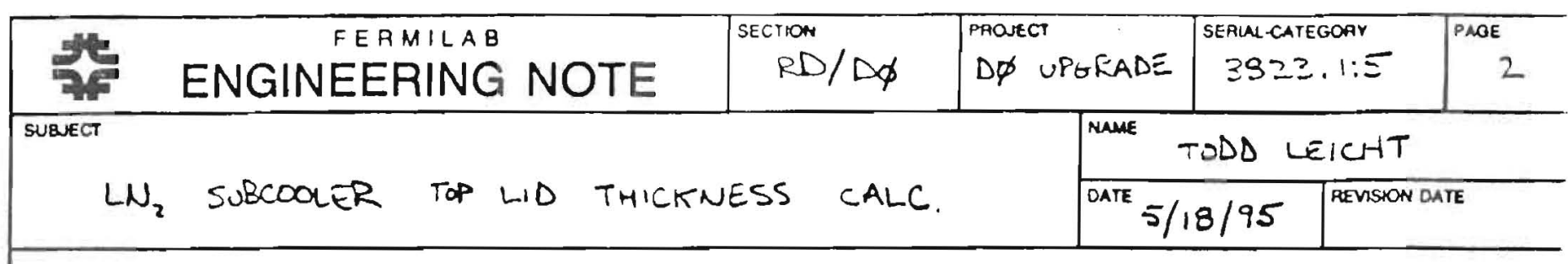

I WILL FLOW SECTION VIII, BN. 1 , APPENDIX 2 To BOLT LOAD W.

2-1 SCOPE: "Proper allowance shaLl be made if connections ARE SUBJECT TO EXTERNAL LOADS OTHER THAN EXTERNAL PRESSURE,"

THIS wOULD INCLUDE THE ADOTTIONAL TENSILE STRESS ON THE BOLTS DUE TO THE METHOD OF SUPPORT OF THE SUPSCOLER.

FIGURE 2: METHOD OF $L N_{2}$ SUBCOOLR SUPPORT

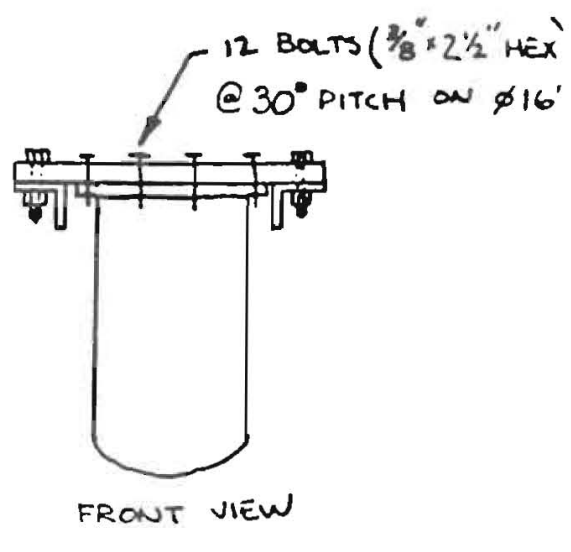

$2-4$ CIRCULAR FLANGE TYPES:

THE DESIGN CONFORMS TO $2-4$ (b) "INTEGRAL TYPE FLANGES"

2-S(e) flange design BOLT LaD W:

CASE (1): OPERATINE CONDITIONS $w=W_{\text {MI }}$ (EON*3)

case (2): GASKET SEATING

$$
W=\frac{\left(A_{m}+A_{b}\right) S_{a}}{2} \quad(\text { EON }+4)
$$




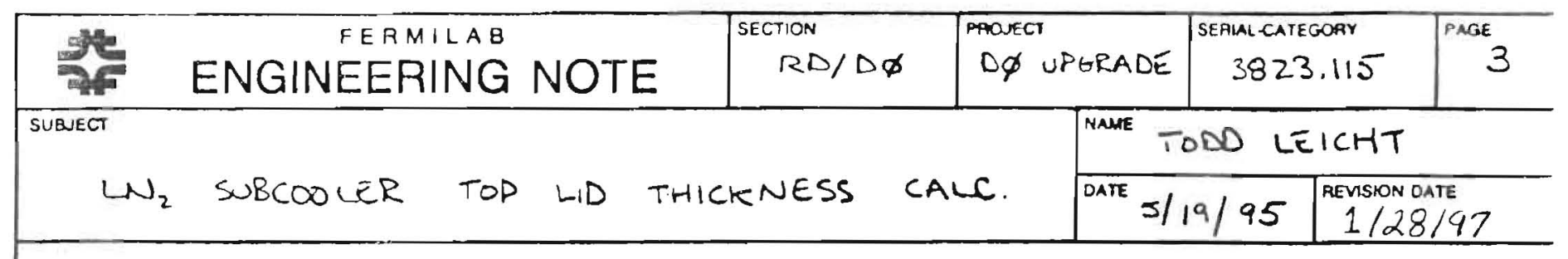

CASE (1): ACCORDING TO 2.5 (C.3) THE USE OF SELF -ENERGIZING GaSkets (O-RINGS) DEMANDS THAT THE REquiRed ROLT LOAD W WI SHALL RESIST THE HYDROSTATIC END FORCE H EXERTED bY the maW. ON THE area bOUNDED BY THE OUTSIDE DIA of THE GASKeT. HP =O, unLESS AXIAL LOADS ARE GENERATED BY CONFIGURATION.

$$
\begin{aligned}
& W=W_{M 1}=H=(.785) G^{2} P \\
& W=W_{M 1}=(.785)\left(14.125: n^{2}(50 \text { psi })=7.83016\right.
\end{aligned}
$$

But the BOLTS mUST ALSO CARRY the WEIEHT OF tHE VESSEL AND ITS CONTENTS $\left(L N_{2}\right)$, LETS DETERMINE maximum WEIGHT and asSUME LN $\mathrm{LN}_{2}$ is filled to the BOTTOM OE THE INSULATION.

$$
\begin{aligned}
& V_{\text {SAT. Lb. }}=1.237 \mathrm{cg} g \text { estimate LU VOLUME: } \\
& V=\frac{\pi}{4} D^{2} h \\
& F_{L_{2}}=V / v \\
& V=\frac{\pi}{4}\left(13^{\prime \prime}\right)^{2}\left(16^{4}\right) \approx 1.3 \mathrm{ft}^{3} \\
& \sum_{h}^{D} \\
& F_{\omega_{2}}=\left(1.3 \mathrm{ft}^{3}\right)\left(\frac{62.43^{\mathrm{lb} / \mathrm{st}^{3}}}{1 \% / \mathrm{cc}}\right)\left(\frac{1}{1.237 \mathrm{c/g}}\right)=66 \mathrm{lb} \\
& \text { Estimate } F_{\text {DEwaR }} \approx 100 \mathrm{lb} \\
& \text { THEN, } F_{\text {TOTAL }}=F_{\text {LN/ }}+F_{\text {DEwaR }}=16616 \\
& \text { Let's say } F_{\text {TOTAL }}=200 \mathrm{lb} \text { to be conservative. } \\
& \text { FINALLY, } \quad W=W_{M 1}+F_{\text {TotaL }}=8,030 \mathrm{lb}
\end{aligned}
$$




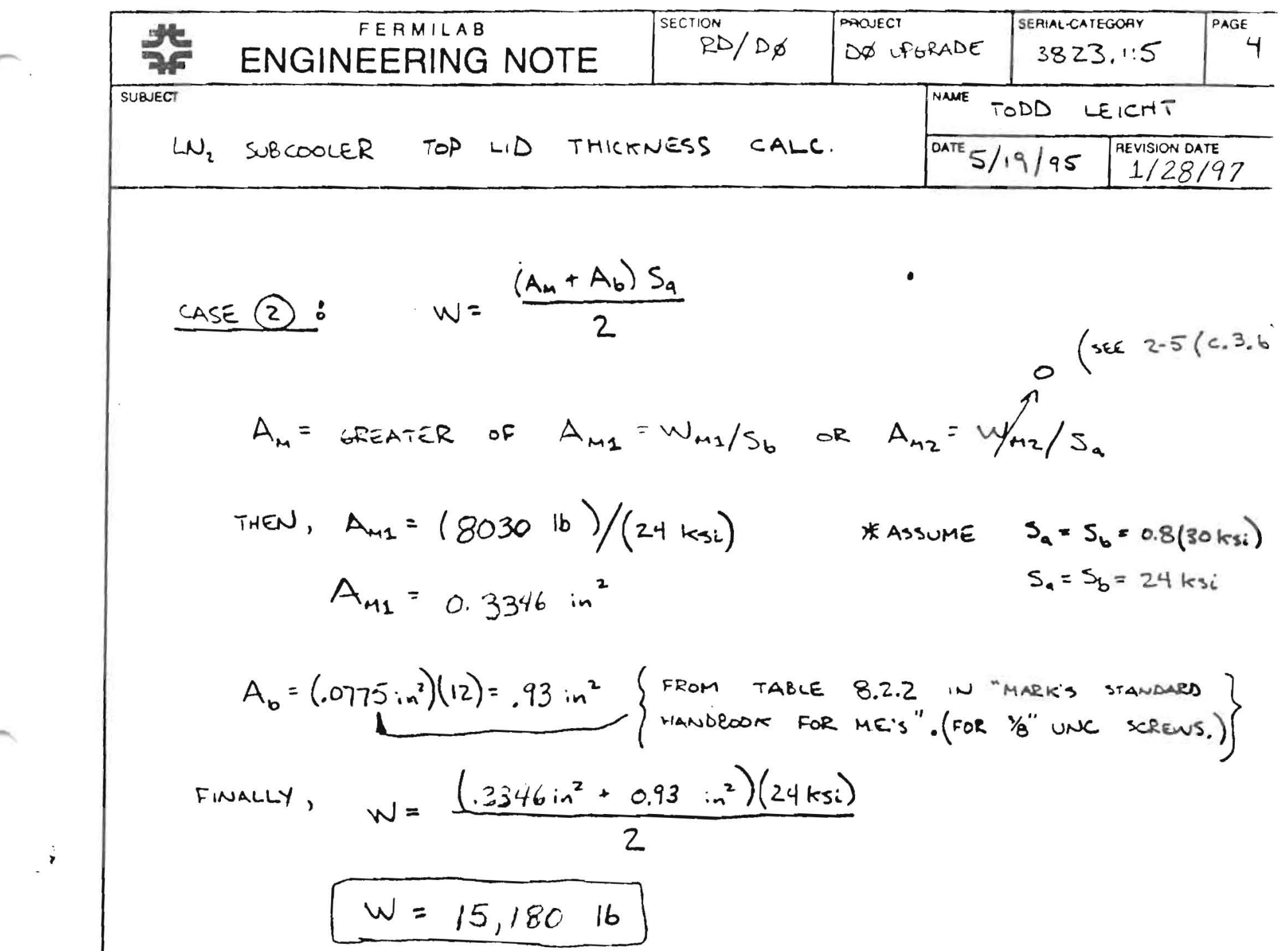

$\therefore$ the max. Bolt load is due to gasket seating (CASE 2) AND is $W=15,180 \mathrm{lb}$.

we can now find $t_{t}$, required plate thickness:

using can 42 on page 1 ,

$$
\begin{gathered}
t_{r}=\left(14.125^{\prime \prime}\right) \sqrt{\frac{(.3)\left(50 p_{s i g}\right)}{(15.04 \mathrm{ksi})(1.0)}+\frac{(1.9)(15.18 \mathrm{kips})\left(.9275^{\prime \prime}\right)}{(15.04 \mathrm{ksi})(1.0)\left(14.125^{\prime \prime}\right)^{3}}} \\
t_{r}=0.571 \mathrm{in}
\end{gathered}
$$




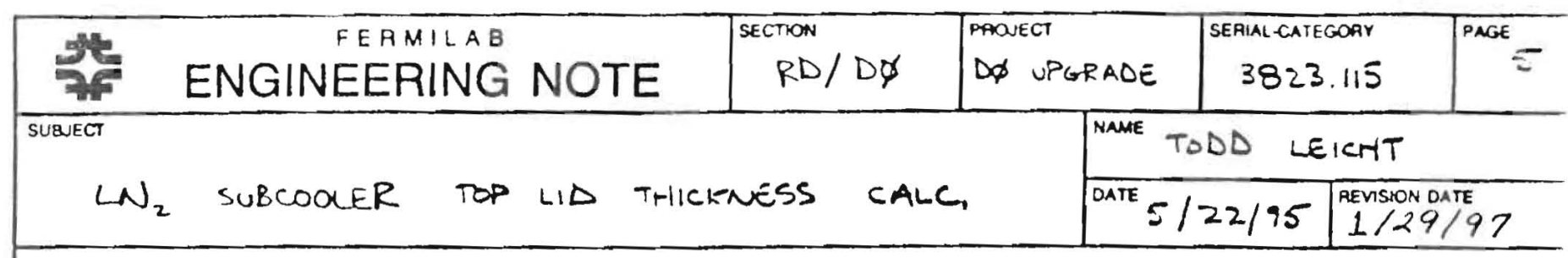

NOW LETS CONSIDER THE NECESSARY REINFORCEMENT DUE TO the many openings in the flat mead, seE apPENDIX "B" FOR DETAILS.

UG-39 REINFORCEMENT REDID FOR OPENINGS IN FLAT HEADS 8

UG-39(b.2) FOR MULTIPLE OPENINGS CAN BE REINFORCED WHEN SPACING BETWEEN ANY PAIR IS $\geq 2$ (DAVE) OF THE PAR.

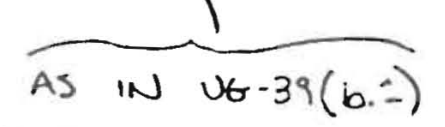

Uo-39(b.1) REQUIRES: $A=0.5 d t=$ X-SESTIONAL AREA OF REINFORCEMENt

$$
\begin{aligned}
& A_{1 \% 2^{\prime \prime S H 10}}=(0.5)(1.682 \mathrm{in})(.571 \mathrm{in}) \quad A_{2^{4} \mathrm{scrs}}=(.5)(2.245 \mathrm{in})(.571 \mathrm{in}) \\
& A_{1 / 2}=0.480 \mathrm{in}^{2} \\
& A_{2^{*}}=0.641: \text { in }^{2}
\end{aligned}
$$

26-40 LIMITS OF RENFORCEMENT:

(b) USE' THE LAREER OF : 'd OR $R_{n}+t_{n}+t$ FROM FIG. UG-37.1. SEE APPENDIX $B$.

$$
\begin{array}{ll}
d_{1 x^{2}}=1.682 \mathrm{in}, & R_{n}+t_{n}+t=(.0841)+(.109)+(.75)=0.943 \mathrm{in} \\
d_{2^{n}}=2.245 \mathrm{in}, & R_{n}+t_{n}+t=(1.123)+(.065)+(.75)=1.938 \mathrm{in}
\end{array}
$$

(c) USE THE SHALLER OF : $2.5 \mathrm{t}$ OR $2.5 \mathrm{ta}_{\mathrm{a}}$

$$
2.5(t)=2.5\left(.75^{\prime \prime}\right)=1.875 \mathrm{in,} \quad \begin{aligned}
2.5\left(t_{n}\right) & =2.5\left(.109^{\prime \prime}\right)=0.273 \mathrm{in} \quad 112^{\prime \prime} \mathrm{scm:} \\
2.5\left(t_{n}\right) & =2.5\left(.065^{\prime \prime}\right)=0.163 \mathrm{in} 2^{\circ} \mathrm{scms}
\end{aligned}
$$

(d) DETERMINE METAL WITHIN LIMITS OF REINFORCEMENT THAT maY BE cONSIDERED to haVE REINFORGING VALUE. 


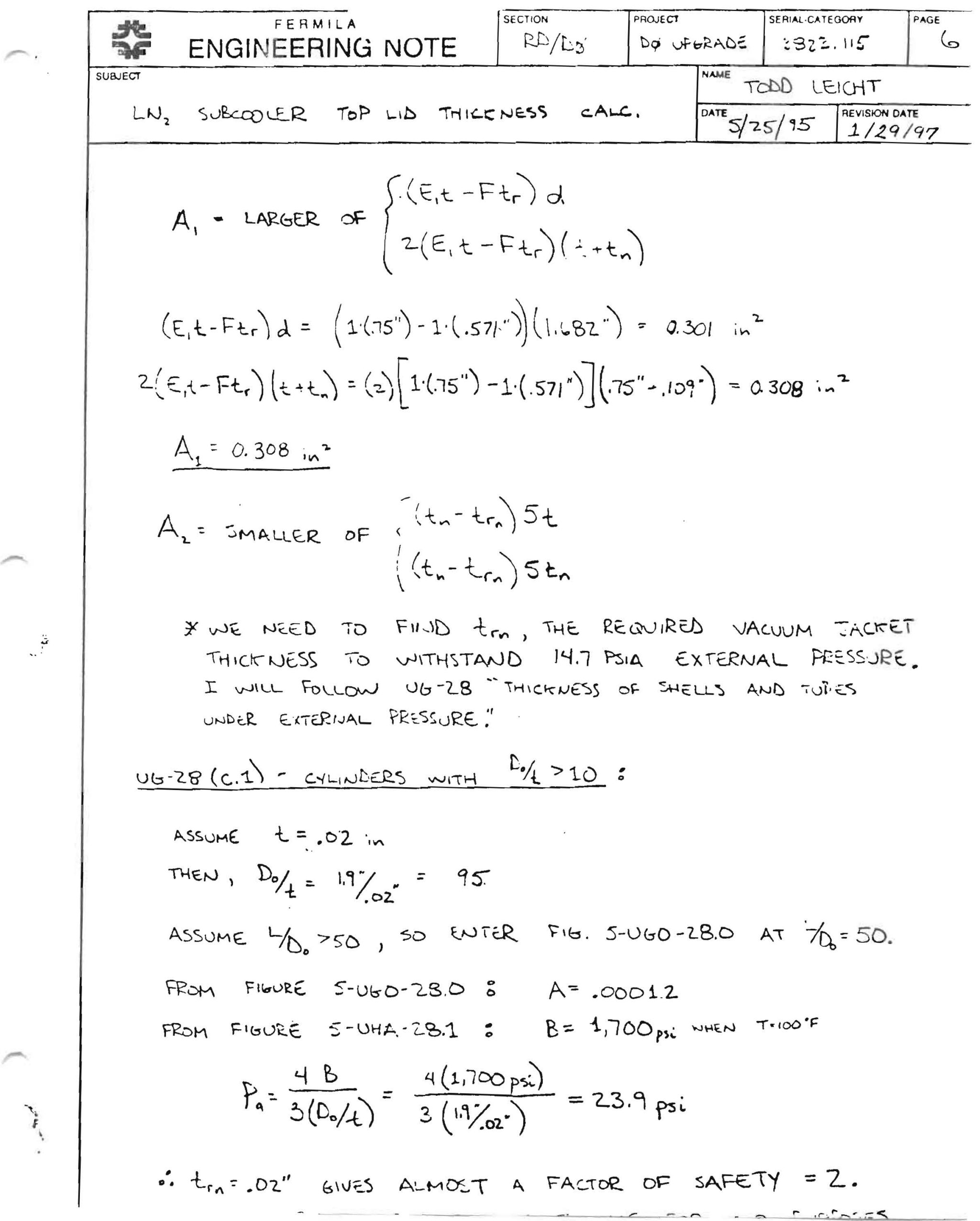




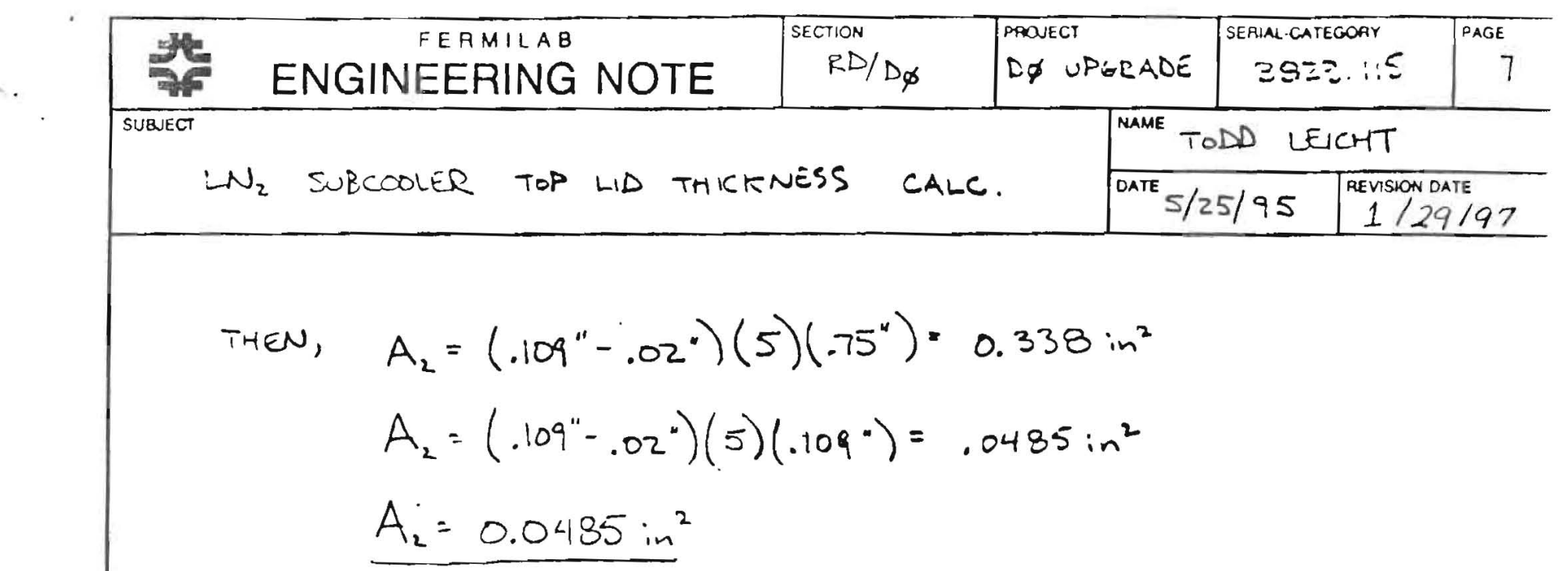

Also assume 1/4" fillet welds on outside $\dot{\xi}$ iNGLE of HEAD.

THEN,

$$
\begin{gathered}
A_{41}=A_{43}=(1 \mathrm{eg})^{2} f_{r_{2}}=\left(.25^{\prime \prime}\right)^{2}(1)=.0625 \mathrm{in}^{2} \\
? \\
A_{1}+A_{2}+A_{41}+A_{43} \geq A \\
\left(.308 \mathrm{in}^{2}\right)+\left(.0485 \mathrm{in}^{2}\right)+2\left(.0625 \mathrm{in}^{2}\right) \geq A \\
0.4815 \mathrm{in}^{2}>0.473 \mathrm{in}^{2} \\
\quad\left(\text { A ActuAL }>A_{\text {REQ D }}\right)
\end{gathered}
$$

$\therefore$ THERE IS ENOUGH REINFORCEMENT AREA FOR THE. $11 / 2$ " SCH 1O V.J.'S WITH 1/4" FILLET WELDS ON BOTH SIDES. SEE APPENDIX " $C$ " FOR CALC'S ON REINFORCING THE $2 " V . J$. FOR THE GR 2 VENT. 


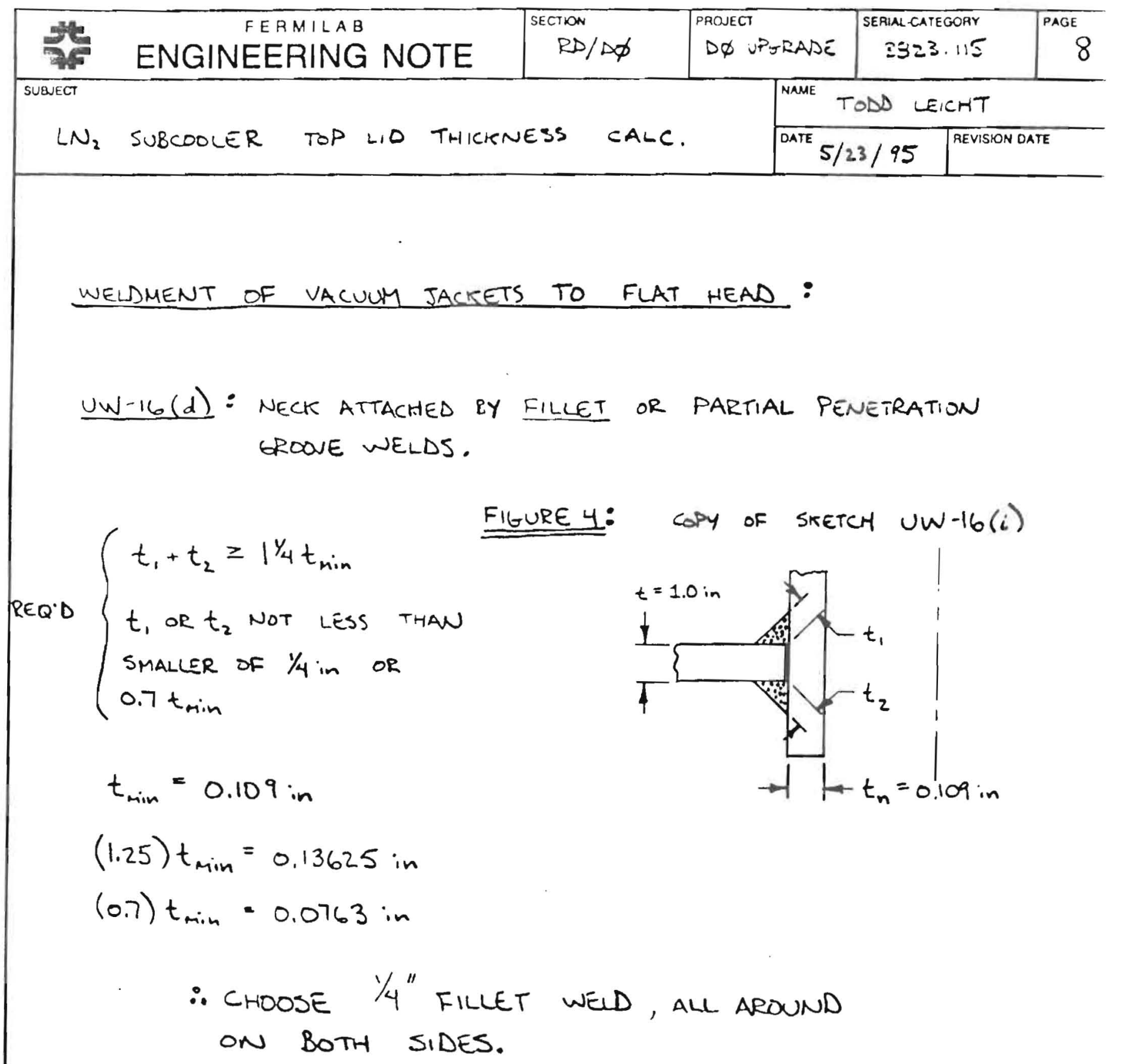




\section{APPENDIX "B"}

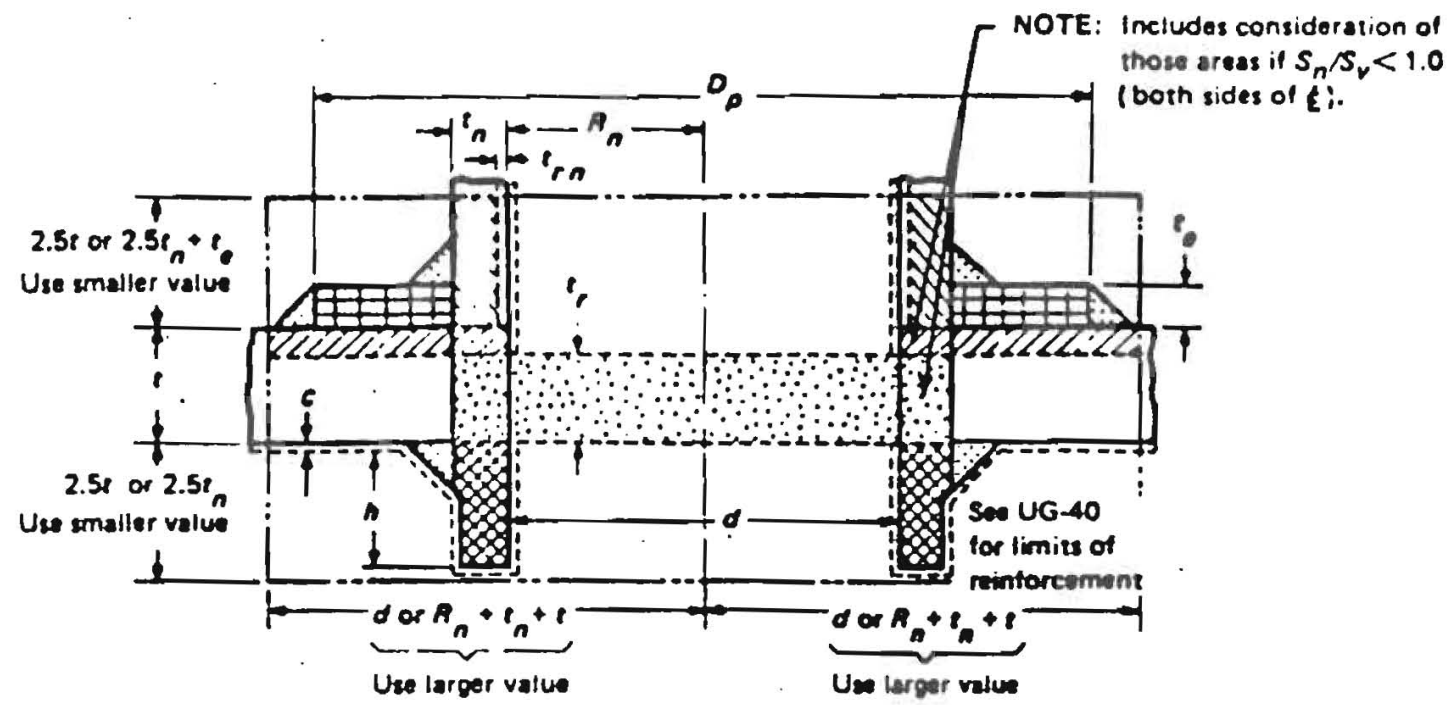

Without Roinforcing Elomem

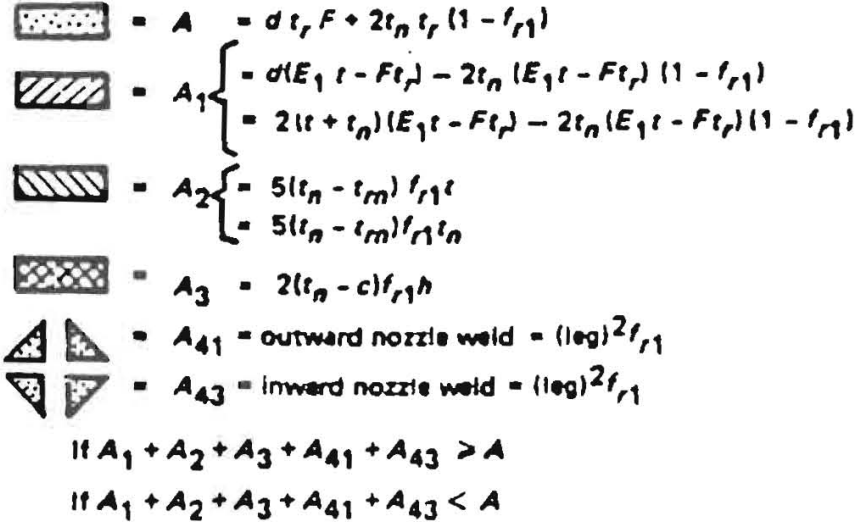

With Reinforcing Element Added
Ares required

Ares ureilable in athell; use lerger value

Area evailable in nozzle projecting outwara: use smolier velue

Aree waileble in inward nozzle

Area wailable in outwerd weid

Ares available in inward weld

Opening is edequately reinforced

Opening is not edequately reinfored so reintoreing elements must be sodded and/or thickness must be increased

Ares requined

Area nuilatio

Ares eveilabte in nozzle profecting outwerd: ue miler are

Ares mailable in inward nozzte

Area eveilebte in outwerd weld

Ares mailable in outer weld

Ares evailable in inverd weld

Area mailable in element

Opening is adequartely reinforced

FIG. L-7 EXAMPLE OF A REINFORCED OPE.VING (This Figure Illustrates a Common Nozzle Configuration and is Not Intended to Prohibit Other Configurations Permitted by the Code.) 


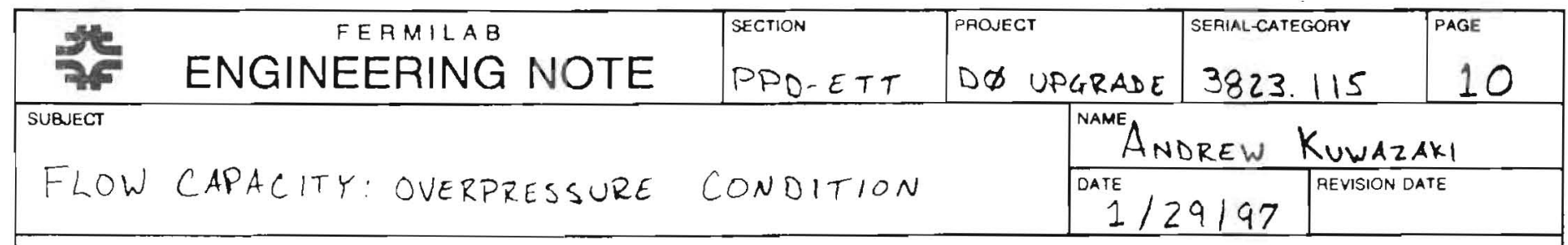

the relief valves chosen are two ago safetyRelief VALVES, $81 M S 44-4$, WITH 1/2" NOMINAL PIPE THREADS FOR BOTH THE INLET AND OUTLET. THE SET PRESSURE IS 50 PSI.

CALCULATING the Flow CAPACITY using the agc CAPACITY CHARTS AT $110 \%$ OVERPRESSURE AND A 50 PSI SET PRESSURE:

INTERPOLATING fOr a SUPPLY PRESSURE OF 50 PSI:

$$
\begin{array}{cc}
\text { SIP } & \text { FLOW CAPACITY } \\
\text { (PSI) } & \text { (SCAM AIR) } \\
40 & 43 \\
50 & 7 \\
60 & 59
\end{array} \Rightarrow Q_{a}=51 \text { SCAM AIR }
$$

Also, the pressure at the valve inlet during FLOW IS PROPORTIONAL TO THE FLOW CAPACITY:

$$
P_{1} \prec V
$$

THEREFORE:

$$
\begin{aligned}
& (40+14.7) \mathrm{PSIA} \times 1.10=60.17 \mathrm{PSIA} \\
& (50+14.7) \mathrm{PS} 1 \mathrm{~A} \times 1.10=71.17 \mathrm{PS} / \mathrm{A} \\
& (60+14.7) \mathrm{PSIA} \times 1.10=82.17 \mathrm{PSIA}
\end{aligned}
$$

$$
\begin{aligned}
& \frac{60.17 \text { PSIA }}{71.17 \text { PSIA }}=\frac{43 \text { SEEM AIR }}{51 \text { seEm AIR }} \\
& 0.845 \approx 0.843 \text { OK. }
\end{aligned}
$$

THE FLOW CAPACITY, $Q_{a}=51$ SCAM AIR 


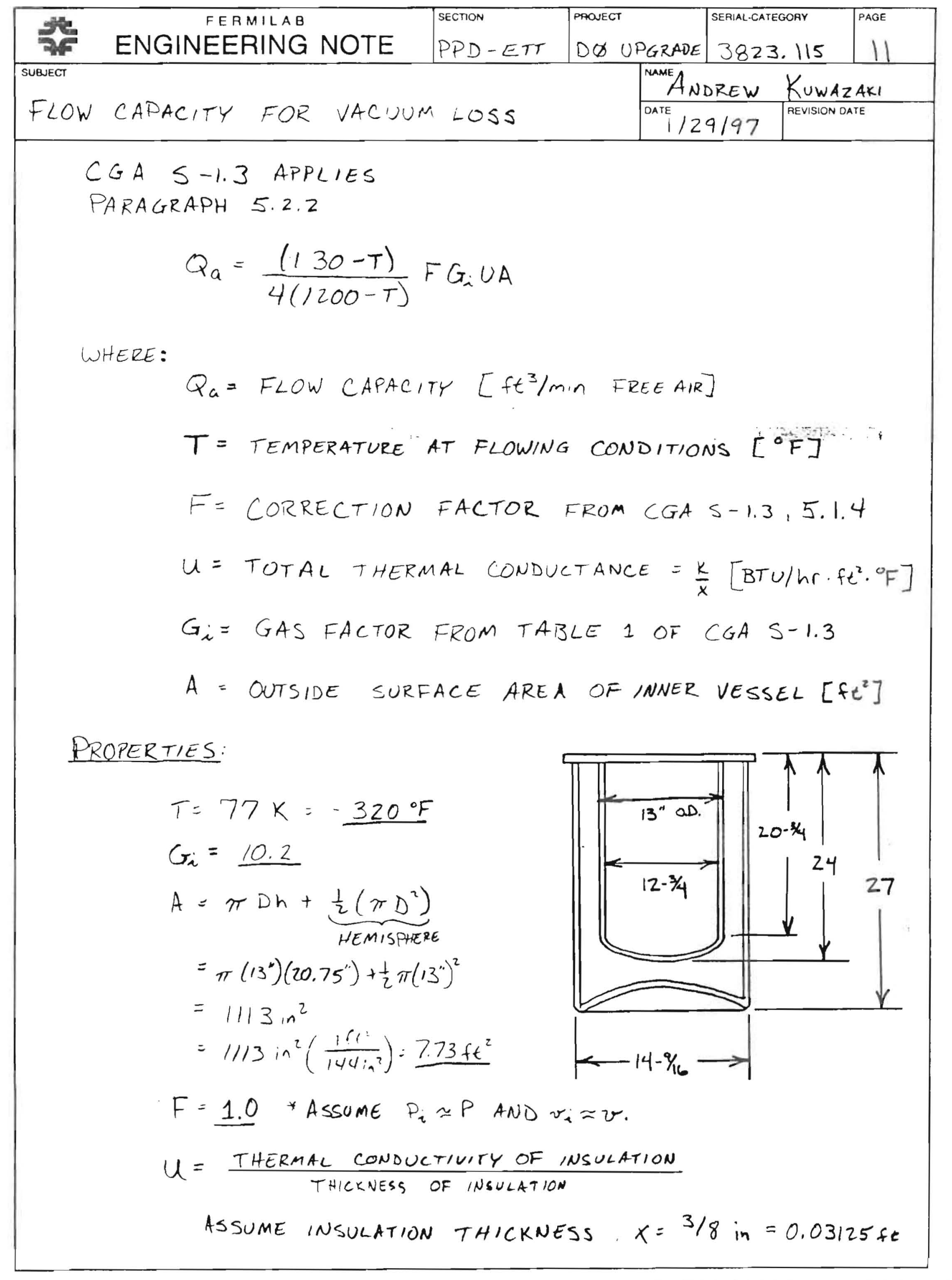




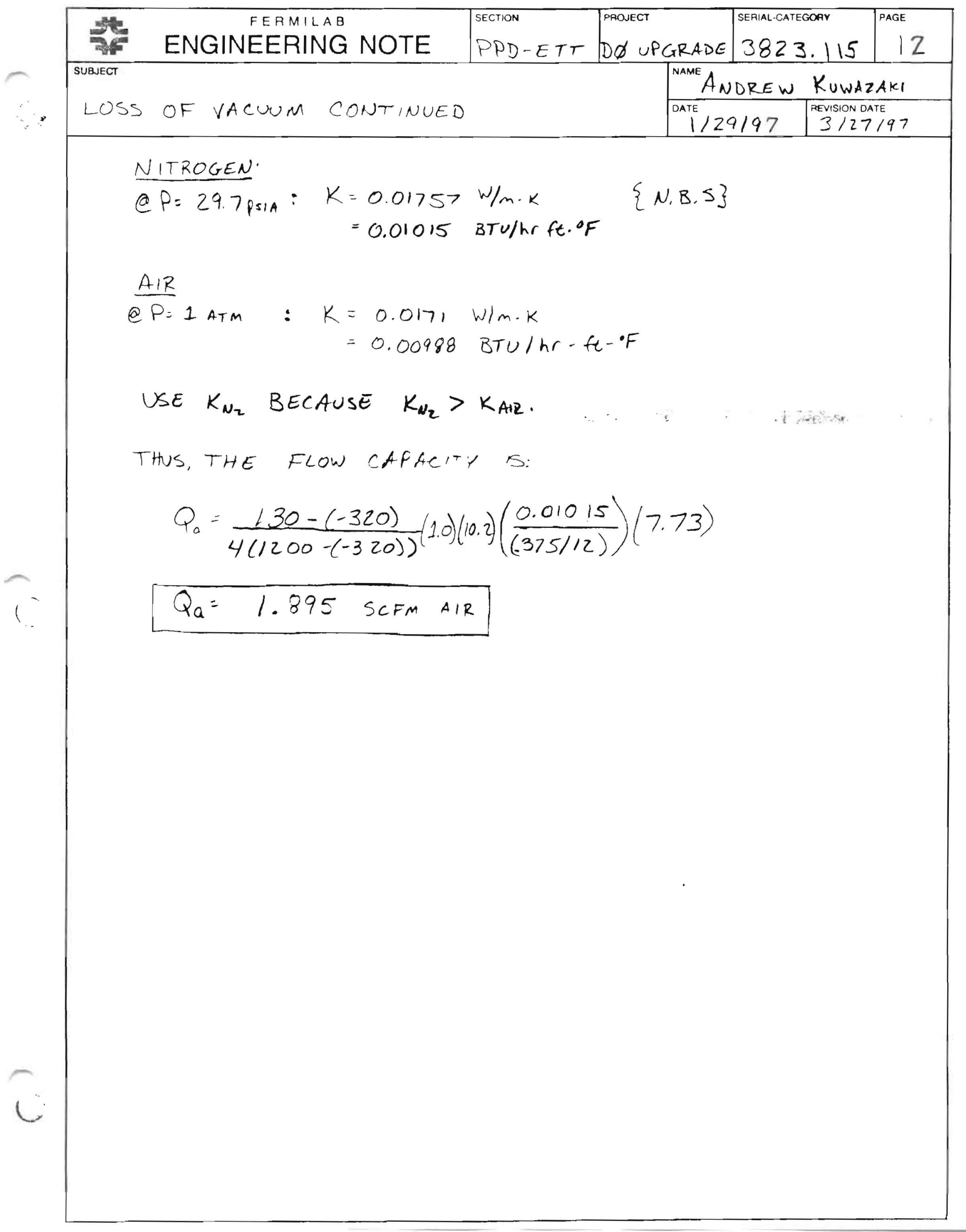




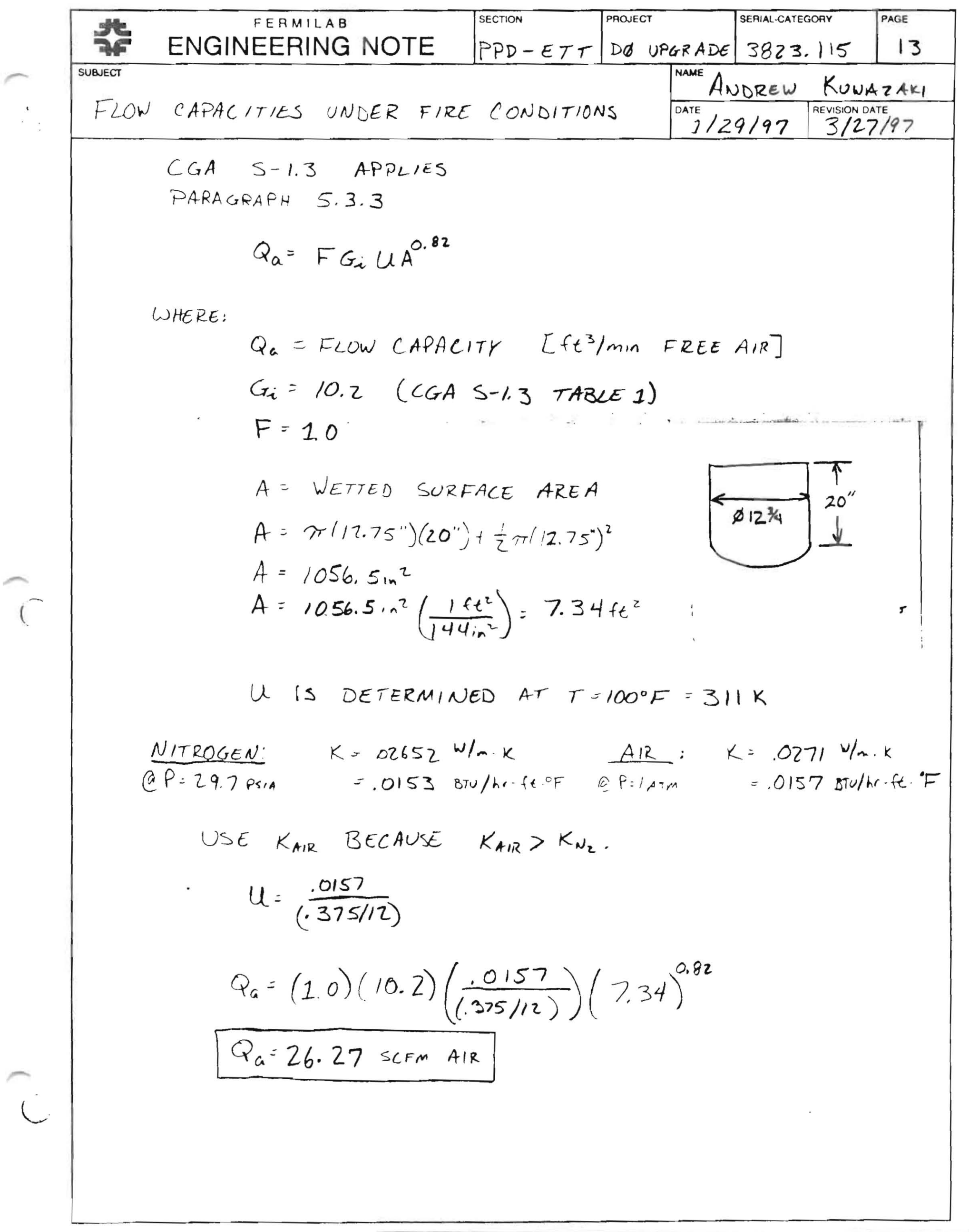




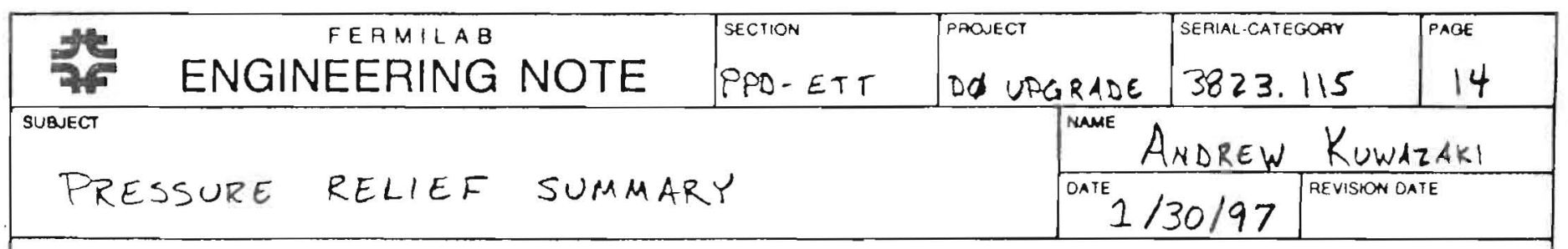

NO OtHER RELIEVING CONDITION, OtHER thAN FIRE AND LOSS OF VACUUM, ARE NEEDED. THIS IS DUE TO THE FACT THAT THE LIQUID NITROGEN SUPPLY DEWAR NORMALLY GEEATES AT 35 PSIG, WHICH IS 15 PSIG BELOW THE MAXIMUM ALIOWABLE WORKING PRESSURE OF 50 PSIG.

NOTE: HELIUM REFRIGERATOR CRYOGENIC FLOW DIAGRAM DRAWINGS ARE PRESENTES N'EXT.

ALSO, WELDER QUALIFICATION AND WELDING PROCEIURE SPECIEICATION HAS BEEN ATTACHED. 


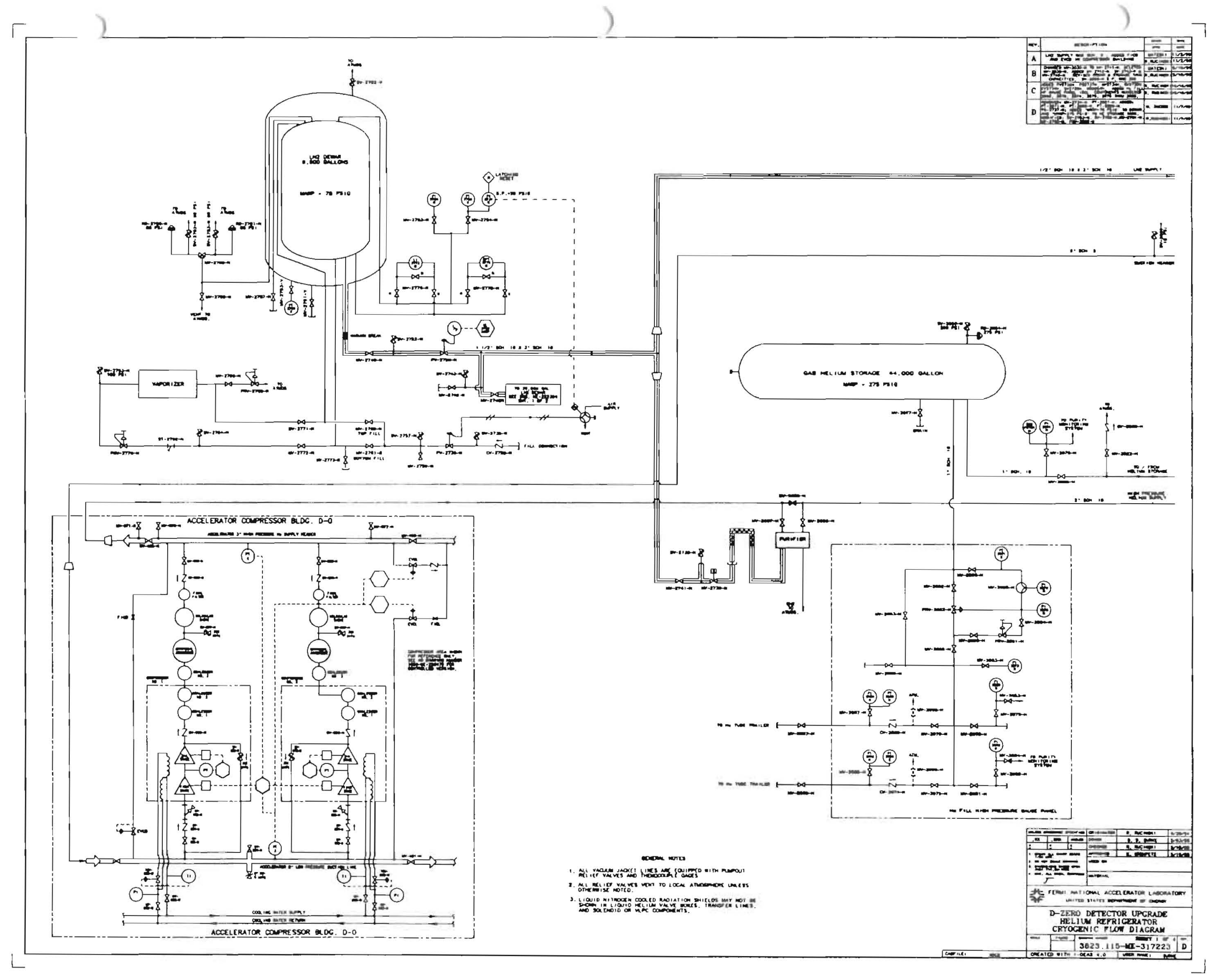




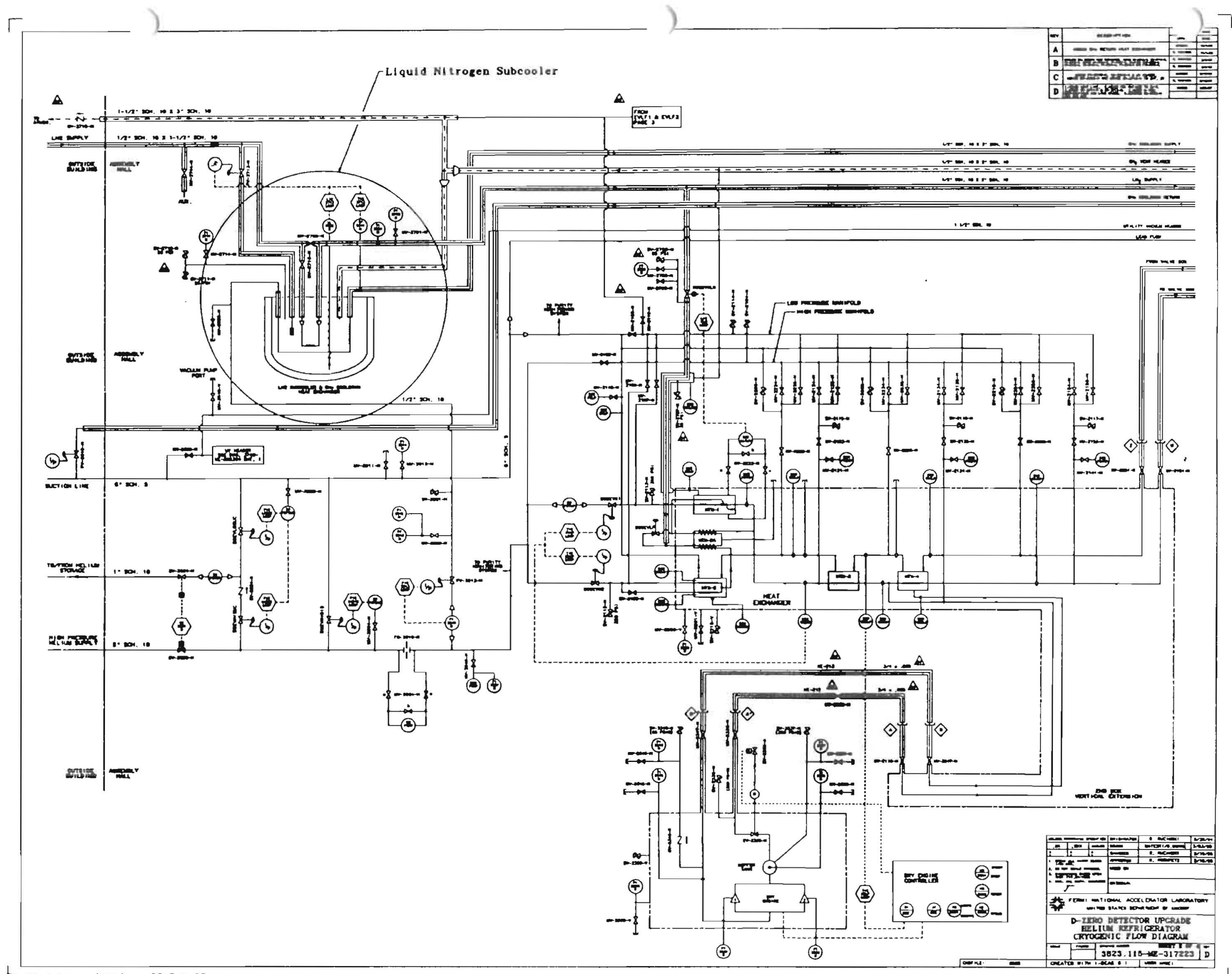




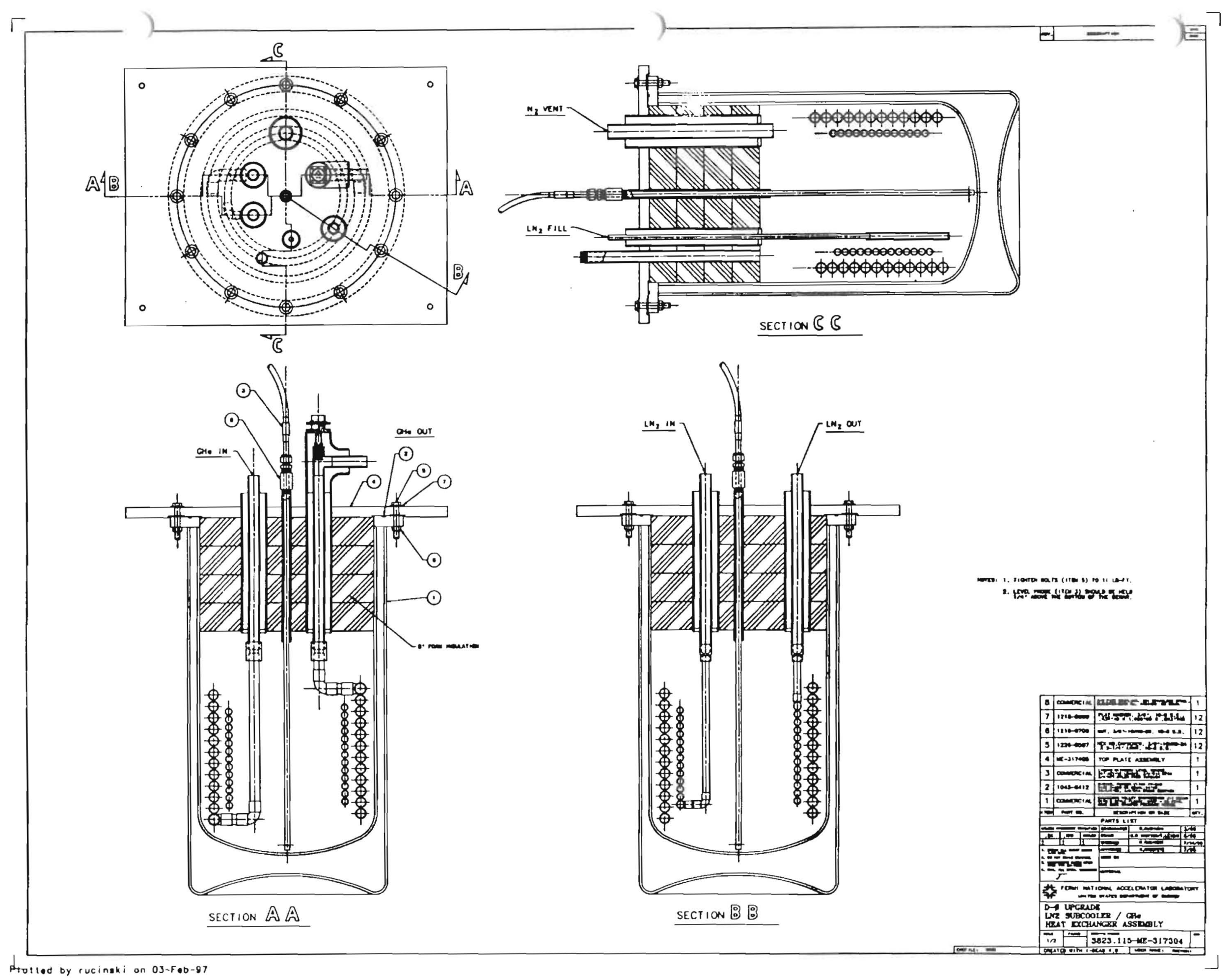

